\title{
Survey of Unexpected Antibodies Identified at a General Hospital in Jeju
}

\author{
Moosang Chong ${ }^{1}$, Kyu-taeg Lee ${ }^{2}$, Young-Kuk Cho ${ }^{3}$ \\ ${ }^{1}$ Department of Clinical Laboratory Science, Cheju Halla University, Jeju, Korea \\ ${ }^{2}$ Department of Laboratory Medicine, Cheju Halla General Hospital, Jeju, Korea \\ ${ }^{3}$ Department of Medical Laboratory Science, Seoyeong University, Gwangju, Korea
}

\section{제주지역 일개 종합병원에서 동정된 비예기항체의 실태조사}

\author{
정무상 ${ }^{1}$, 이규택 ${ }^{2}$, 조영국 ${ }^{3}$ \\ ${ }^{1}$ 제주한라대학교 임상병리과, ${ }^{2}$ 제주한라병원 진단검사의학과, ${ }^{3}$ 서영대학교 임상병리과
}

\begin{abstract}
Unexpected antibody screening and identification tests are highly important in the prevention of hemolytic transfusion reactions. Therefore, it is highly recommended to perform unexpected antibody screening test in all transfusion candidates. Here, the frequency and distribution of unexpected antibodies identified in Jeju for the past 3 years were evaluated. Between Jan 2014 and Dec 2016, unexpected antibody screening test was performed for 10,360 sera of transfusion candidates in Jeju general hospital using a column agglutination method with the Ortho BioVue system (Ortho-clinical Diagnostics, Raritan, NJ, USA). Eighty-seven (0.84\%) of 10,360 cases that underwent unexpected antibiotics screening showed positive results. Among them, unexpected antibodies were identified in 41 cases $(0.40 \%)$. Unidentified antibodies were detected in 8 cases (19.51\%) and autoantibodies were detected in 3 cases (7.32\%). The anti-E antibody included in warm antibodies were detected most frequently in 8 cases $(19.51 \%)$; 6 cases $(14.63 \%)$ of anti-E +

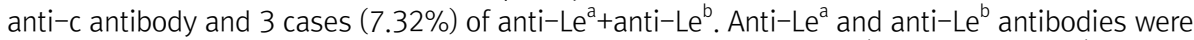
detected in 2 cases (4.88\%), respectively. The anti-D, anti-Di ${ }^{\mathrm{a}}$, anti-Fy ${ }^{\mathrm{b}}$, anti-Jk ${ }^{\mathrm{a}}$, anti-J $\mathrm{k}^{\mathrm{b}}$, anti-M and anti-P1 were detected in 1 case (2.44\%). Complex antibodies were detected in 1 case $(2.44 \%)$ in anti-C+anti-D and anti-E+anti-c+anti-Jk ${ }^{\mathrm{b}}$, respectively. In this study, we analyzed the frequency and distribution of unexpected antibodies in one general hospital for the past 3 years. However, there has been a general increase in multicultural families and foreign workers in Jeju, and it would be a meaningful study to compare the frequency and distribution of unexpected antibodies.
\end{abstract}

Key words: Antibody screening test, Antibody identification test, Unexpected antibody

This is an Open Access article distributed under the terms of the Creative Commons Attribution Non-Commercial License (http://creativecommons.org/licenses/by-nc/4.0) which permits unrestricted non-commercial use, distribution, and reproduction in any medium, provided the original work is properly cited.

Copyright (C 2017 The Korean Society for Clinical Laboratory Science. All rights reserved.
Corresponding author: Moo Sang Chong Department of Clinical Laboratory Science, Cheju Halla University, 38 Halladaehak-ro, Jeju 63092, Korea

Tel: 82-64-741-6732

Fax: 82-64-741-6729

E-mail: chong@chu.ac.kr

Received: November 14, 2017

Revised $1^{\text {st: }}$ November 16, 2017

Revised $2^{\text {nd: }}$ : November 19, 2017

Revised 3 ${ }^{\text {rd }}$ : November 20, 2017

Accepted: November 20, 2017

\section{서 론}

수혈로 인한 부작용은 여러 가지의 원인이 있지만, 용혈성 수 혈 부작용의 중요한 원인 중의 하나로 $\mathrm{ABO}$ 부적합 이외에 비예 기항체에 의한 수혈부작용의 빈도가 증가하고 있어, 수혈로 인 한 부작용을 최소화하고 수혈의 안전성을 높이기 위해 대부분
의 수혈을 시행하는 의료기관은 비예기항체 선별검사를 실시하 고 있다. 지연성 용혈성 수혈부작용은 수혈 후 3 13일 정도에 설명되지 않은 비예기항체가 생성되어 용혈반응이 발생하게 되 며, 환자가 사망에 이를 수도 있다. 이러한 이상반응을 초래하는 비예기 항체로는 Rh항체 및 kidd, Duffy, kell 항체 등이 현재 알 려져 있다[1,2]. 
비예기항체(unexpected antibody)는 $\mathrm{ABO}$ 혈액형 항체와 는 달리 존재 여부를 미리 예측할 수 없는 항체로 주로 임신이나 수혈 등에 의해 다른 적혈구 항원에 노출됨으로써 발생하는 면 역항체로서, 비예기항체는 해당 항원을 가진 수혈된 적혈구를 파괴하여 급성 및 지연성 용혈성부작용이나 신생아용혈성질환 등의 수혈부작용을 유발할 수 있다[3-5].

이런 비예기항체는 혈액형을 결정하거나수혈시 교차반응을 어렵게 하므로 부적합 수혈이 이루어 질 수 있고, 비예기항체를 발견하지 못하고 수혈할 때에는 용혈성 수혈 부작용을 일으킬 수 있으므로 비예기항체의 검출은 수혈시 매우 중요하다. 즉, 비 예기항체 선별검사를 실시하여 혈청내 존재 가능성이 있는 비 예기항체에 대한 동정이 이루어지면 수혈 안전성 확보에 도움 이 된다. 또한 항체 역가가 낮아서 주교차 적합성 검사상 위음성 결과로 인하여 지연성 용혈성 수혈부작용을 예방할 수 있고 혈 액형 판독의 혼선을 피하는데도 도움을 줄 수 있다[6].

항체선별검사는 수혈자의 혈청 내에 비예기항체가 존재하는 지를 판단하는 검사로 $\mathrm{ABO}$ 항체 이외의 적혈구 불규칙항체를 선별하는 검사이다. 임상적으로 중요한 적혈구 항원을 가지고 있는 O형 선별용 혈구와 환자의 혈청을 식염수, 알부민, 항글로 부린 방법을 이용하여 반응시킴으로써 미지의 적혈구 불규칙항 체의 존재를 선별한다. 비예기항체는 검사를 하기 전에는 존재 여부를 알 수 없는데, 이러한 항체를 가진 사람이 여기에 반응하 는 항원을 가진 적혈구를 수혈 받게 되면 용혈성 수혈부작용과 같은 문제가 생길 수 있기 때문에, 수혈자의 혈청과 임상적으로 중요한 항원들을 지닌 적혈구를 반응시켜 비예기항체의 유무를 검사하여 양성반응을 보이면 혈청을 11 가지의 다양한 항원 조 합의 동정혈구들과 반응시켜 그 결과를 분석함으로써 항체의 특이성을 확인하는 항체동정검사를 실시한다. 이러한 수혈전 비예기항체 선별 및 동정검사는 매우 중요하며 수혈이 필요한 환자에게 수혈로 인한 부작용을 최소화하고 수혈의 안전성을 높이기 위해 실시하고 있다[7-9].

비예기항체 선별검사 방법으로는 시험관법, micro-plate법 그리고 1980년대초 Lapierre 등[10]에 의해 개발된 원주응집 법이 있으며, 각 의료기관의 검사 목적이나 사정에 따라 다양한 검사 방법을 채택하고 있다. 이러한 방법의 차이로 국내 비예기 항체의 분포에 대한 연구 결과도 서로 다른 결과를 보이고 있는 데, 시험관법을 이용한 연구에서는 anti-Le $\mathrm{L}^{\mathrm{a}}$, anti-P1, anti-Le ${ }^{\mathrm{b}}$ 등 주로 실온에서 반응하면서 임상적으로 큰 문제가 없는 한랭 항체가 대다수를 차지하였고, 원주응집법을 이용한 연구에서 는 anti-E와 anti-c 등 임상적으로 문제를 일으킬 수 있는 온난 항체가 anti-Le ${ }^{\mathrm{a}}$ 보다 높은 빈도를 나타내고 있다[11,12].
이와 같이 비예기항체의 검출빈도 및 분포는 검사방법, 연구 대상, 유전자빈도, 그리고 항글로부린의 중화, 그리고 혈청의 점 도 등에 따라차이를 보이는 것으로 알려져 있다 $[8,13,14]$. 이에 본 연구는 제주지역에 위치한 $\mathrm{H}$ 종합병원에서 2014년부터 2016년까지 3년간 비예기항체 선별검사 및 동정검사가 의뢰된 환자를 대상으로 비예기항체 선별 및 동정검사의 결과를 기존 의 연구결과와 비교하고 제주지역 비예기항체의 빈도 및 분포 를 분석하였다.

\section{재료 및 방법}

\section{1. 대상}

2014년 1월부터 2016년 12월까지 3년간 제주특별자치도 $\mathrm{H}$ 종합병원에 비예기항체 선별검사가 의뢰된 10,360 명의 혈청 검체를 대상으로 하였으며, 의뢰된 비예기항체 선별결과 양성 결과를 보인 87 검체를 대상으로 조사하였다. 검사방법은 Ortho BioVue system (Ortho-clinical Diagnostics, Raritan, $\mathrm{NJ}, \mathrm{USA}$ )을 이용한 원주응집법으로 시행하였다.

\section{2. 검사방법}

검사방법으로는 Ortho BioVue AHG Cassette (Ortho-clinical Diagnostics, Raritan, NJ, USA)에 LISS $40 \mu \mathrm{L}$ 씩 분주한 후, Selectogen I, II (Ortho-clinical Diagnostics, Raritan, NJ, $\mathrm{USA}$ 를 각각 $10 \mu \mathrm{L}$ 씩 넣고 환자 혈청 $40 \mu \mathrm{L}$ 를 첨가하였다. 이 를 $37^{\circ} \mathrm{C}$ 에서 10 분간 반응시킨 후 5 분간 원심 분리하여 결과를 판독하였다. 결과는 음성과 양성(약양성에서 $4+$ 까지 모두를 포 함)으로 판독하였다. 비예기항체 선별검사에서 양성으로 나온 검체는 수탁검사기관으로 동정검사를 의뢰하여 얻은 결과로 비 예기항체에 대한 동정확인을 하였다.

\section{결 과}

\section{1. 연도별 비예기항체 동정 빈도}

비예기항체 선별검사가 의뢰되었던 전체 10,360 건 중 양성 은 87건(0.84\%)이었다. 이를 연도별로 보면, 2014년에 의뢰되 었던 3,147건 중에는 양성이 32건(1.02\%), 2015년에는 3,354 건 중 26 건(0.78\%), 2016년은 3,859건 중 29건(0.75\%)이 양성 이었다.

\section{2. 비예기항체 종류별 분포}

비예기항체가 선별되었던 87건 중 비예기항체 동정검사를 
Table 1. The frequency and distribution of unexpected antibodies (single antibodies) detected at a general hospital in Jeju

\begin{tabular}{cccc}
\hline Blood type system & Antibody specificity & No. & $\%$ \\
\hline Rh & Anti-E & 8 & 19.51 \\
& Anti-D & 1 & 2.44 \\
Lewis & Anti-Le $^{\mathrm{a}}$ & 2 & 4.88 \\
& Anti-Le $^{\mathrm{b}}$ & 2 & 4.88 \\
Kidd & Anti-Jk $^{\mathrm{a}}$ & 1 & 2.44 \\
& Anti-Jk $^{\mathrm{b}}$ & 1 & 2.44 \\
Duffy & Anti-Fy $^{\mathrm{b}}$ & 1 & 2.44 \\
Diego & Anti-Di $^{\mathrm{a}}$ & 1 & 2.44 \\
MNSs & Anti-M $^{\mathrm{A}}$ & 1 & 2.44 \\
P & Anti-P1 & 1 & 2.44 \\
Total & & 19 & 46.34 \\
\hline
\end{tabular}

수탁검사기관으로 의뢰한 41 검체( $0.40 \%)$ 대상으로 분석한 결 과 비특이항체가 8건(19.51\%), 자가항체가 3건(7.32\%)이었다. 이들을 제외하고 항체가 동정된 것은 anti-E가 8건(19.51\%), anti-E, anti-c 복합항체가 6건(14.63\%), anti-Le ${ }^{\mathrm{a}}$, anti-Le ${ }^{\mathrm{b}}$ 복 합항체가 3 건(7.32\%), anti-Le ${ }^{\mathrm{a}}$ 와 anti-Le $\mathrm{L}^{\mathrm{b}}$ 가 각각 2 건(4.88\%) 으로 조사되었다. 단일항체로는 anti-D, anti- $\mathrm{Di}^{\mathrm{a}}$, anti-Fy anti-Jk ${ }^{\mathrm{a}}$, anti-Jk $\mathrm{k}^{\mathrm{b}}$, anti-M, 그리고 anti-P1이 각각 1건(2.44\%) 로 나타났으며 복합항체로는 anti-C+anti-D, anti-E+anti-c+ anti-Jk $\mathrm{k}^{\mathrm{b}}$ 가 각각 1 건(2.44\%)로 조사되었다. 단일항체가 동정된 검체는 19 건(46.34\%), 복합항체가 동정된 검체는 11 건(26.83\%) 로 나타났다(Table 1, 2).

비예기항체가 동정된 검체의 평균나이는 64.51세 이였으며, 성별의 비율은 남성은 14 건(34.15\%), 여성은 27 건(65.85\%)로 나타났다.

\section{3. 비예기항체 특징}

비예기항체가 동정된 41 검체 중 Rh 계열과 Lewis 계열의 항 체가 가장 많은 빈도로 조사되었으며, Diego 계열의 항체가 동 정된 것은 주목할 만 하다. 또한 복합항체의 빈도는 Anti-E 와 Anti-c가 동시에 발견된 예가 가장 많은 분포를 하고 있었으며, $\mathrm{Rh}$ 계열과 Kidd 계열의 복합항체로 Anti-E와 Anti-c, 그리고 anti-Jk $\mathrm{b}^{\mathrm{b}}$ 가 동시에 발견된 예는 특이할 만하다고 생각된다.

\section{고 찰}

비예기항체는 대개 $\operatorname{IgG}$ 항체로 실온에서 생리식염수에 부유 된 적혈구를 응집시키지 못하므로 불완전항체라고 부르기도 한 다. 그러므로 비예기항체에 의한 용혈성 수혈부작용을 예방하 기 위해서는 수혈 전 교차시험에 반드시 $37^{\circ} \mathrm{C}$ 항온단계와 항글 로불린 단계를 포함시켜야 임상적으로 중요한 항체의 존재 여
Table 2. The frequency and distribution of unexpected antibodies (complex antibodies) detected at a general hospital in Jeju

\begin{tabular}{cccc}
\hline Blood type system & Antibody specificity & No. & $\%$ \\
\hline Rh & Anti-E+Anti-c & 6 & 14.63 \\
& Anti-C+Anti-D & 3 & 7.32 \\
Rh+Kidd & Anti-E+Anti-c+anti-Jk & 1 & 2.44 \\
Lewis & Anti-Le ${ }^{\mathrm{a}}$, Anti-Le & 1 & 2.44 \\
& Total & 11 & 26.83 \\
\hline
\end{tabular}

부를 확인할 수 있다. 비예기항체 검사에 대해 원주응집법와시 험관법을 비교한 결과에 의하면, 시험관법에 비해 용혈과 관련 된 항체의 양성률이 더 높게 나타났으며, 자연항체지만 드물게 용혈을 일으키는 항체인 anti-Le ${ }^{\mathrm{a}}$, anti-Le ${ }^{\mathrm{b}}$ 및 anti-P1의 양성 률이 원주응집법에서 더 높게 나타났으며[15], Bromilow와 Adams [16]의 연구에 따르면, 산전 비예기항체검사에서 항체 양성률은 원주응집법에서 $3.7 \%$ 이고 전통적인 시험관법으로는 $2.4 \%$ 이었고, 원주응집법을 사용했을 때 비특이항체와 위양성 이 감소되었으며 항체역가를 검사했을 때 원주응집법에서 더 예민한 것으로 보고되고 있다.

타 지역의 항체동정검사의 양성율을 살펴보면 Cho 등[4]의 연구에 의하면 전라북도 $\mathrm{CNUH}$ 병원에서 동정된 비예기항체의 양성률은 $0.54 \%$ 로 보고되고 있으며, Jung 등[17]의 연구에서 는 경상북도 $\mathrm{KBUH}$ 병원에서 수혈이 요청된 입원환자 중 비예 기항체의 양성률은 0.65\%로 보고되며, Park 등[18]의 연구에 서는 경기도 NCC 병원에서 비예기항체의 양성률은 $0.58 \%$ 로 보고되고 있다.

Shin 등[19]의 연구에서, 비예기항체 선별검사가 의뢰된 72,600 명의 환자 중 467명(0.64\%)에서 양성반응을 보였으며, 선 별검사에서 양성을 보인 467 명 중 324 명의 환자에서 비예기 동종 항체가 검출되었다고 한다. 비예기항체의 빈도는 anti-E가 $37.3 \%$

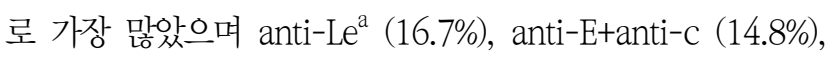
anti-C+anti-e (5.6\%), anti-Le ${ }^{\mathrm{b}}$ (4.9\%), anti-D (4.6\%), $\operatorname{anti}^{-J k^{\mathrm{a}}}$ (3.1\%), anti-S (2.5\%), anti-M (1.9\%) 순으로 조사되 었다고 보고하고 있다. 324 명의 환자 중 74 명(22.8\%)이 한 개 이상의 복합항체 형태를 나타내었고, Anti-c, anti-e, anti-C는 $90 \%$ 이상이 다른 항체와 함께 나타났으며, 반면에 anti-D, anti-Jk $\mathrm{a}^{\mathrm{a}}$, anti-Le ${ }^{\mathrm{a}}$, anti-M, anti-S 등은 대부분이 단독으로 검 출되었다고 한다. $\mathrm{Kim}$ 등[20]의 연구에서는 환자 31,381명 중 540 명이 항체선별검사에서 양성을 보였으며, 그 중에서 동종면 역이 확인된 환자는 188 명이었다. 전체 동종면역 환자 188 명 중 45명에서 복합항체가 발견되어 $23.9 \%$ 의 빈도를 보였으며, 복합항체 중에서 anti-E와 anti-c가 가장 많았고, anti-P1과 anti-K가 가장 드물었다. 가장 흔하게 동정된 복합항체의 조합 
은 anti-E/-c였고 그 다음은 anti-C/-e였다. 동정된 13 가지의 복합항체 조합 중 2가지를 제외하고 나머지는 모두 Rh 항원에 대한 항체가 하나 이상 포함되어 있었다고 보고하고 있다.

$\mathrm{Rh}$ 계열의 비예기항체가 가장 많은 빈도로 나타나며, 우리나 라의 흔한 Rh 표현형은 $\mathrm{CDe}$ 가 약 $40 \%$ 정도를 차지하고 두 번째 로 CcDEe 표현형이 34 38\% 차지한다고 알려져 있다. 헌혈제 제의 Rh 표현형도 이와 비슷할 것이므로 특히 $\mathrm{CcDEe}$ 형의 혈액 이 $\mathrm{CDe}$ 환자에게 수혈할 경우 동종면역으로 인한 anti-E의 생 성이나 anti-E와 anti-c 등이 동시에 발생할 수 있으며, 이 후에 $\mathrm{Rh}$ 항원 E 또는 c가 있는 적혈구 제제 수혈을 다시 받으면 이차 성 지연성 용혈수혈이상반응이 발생할 가능성이 커지게 된다 [21].

본 연구에서도 타 연구와 유사한 결과를 나타냈으며, 비예기 항체 선별검사의 양성율은 $0.84 \%$ 였으며 anti-E가 $19.51 \%$, anti-E, anti-c 복합항체가 $14.63 \%$, anti-Le ${ }^{\mathrm{a}}$, anti-Le $\mathrm{L}^{\mathrm{b}}$ 복합항 체가 7.32\%, anti-Le ${ }^{\mathrm{a}}$ 와 anti-Le 가 각각 $4.88 \%$ 으로 조사되었으 며, 단일항체로는 anti-D, anti-Di ${ }^{\mathrm{a}}$, anti-Fy ${ }^{\mathrm{b}}$, anti-Jk ${ }^{\mathrm{a}}$, anti-Jk $\mathrm{k}^{\mathrm{b}}$, anti-M, anti-P1가 각각 $2.44 \%$, 복합항체로는 anti-C+anti-D, anti-E+anti-c+anti-Jk 가 각각 2.44\%로 조사되었다. Rh 계열 과 Lewis 계열의 항체가 가장 많은 빈도로 조사되었으며, Diego 계열의 항체가 동정된 것은 주목할 만 하다. 또한 복합항 체의 빈도는 Anti-E 와 Anti-c가 동시에 발견된 예가 가장 많은 분포를 하고 있었으며, Rh 계열과 Kidd 계열의 복합항체로 Anti-E와 Anti-c, 그리고 anti-Jk ${ }^{\mathrm{b}}$ 가 동시에 발견된 예는 특이 할 만하다고 생각된다.

제주지역의 종합병원은 제주시와 서귀포시에 위치한 종합병 원 7개 기관이 있으며, 모두 비예기항체 선별검사를 시행하고 있으며, 검사방법으로는 모든 검사실에서 Ortho BioVue system을 이용한 원주응집법으로 검사를 시행하고 있다. 하지 만 비예기항체 동정검사는 외부수탁기관에 의뢰하고 있는 실정 이다. 이번 연구는 최근 3 년간 제주도내 종합병원 1 개 기관에서 의 동정된 비예기항체 빈도와 분포를 분석하였지만, 점차적으 로 제주도내 다문화가정과 외국인 근로자가 증가 추세에 있어 향후 제주지역에 분포한 다수의 종합병원에서 동정되는 비예기 항체의 빈도와 분포를 비교 분석한다면 의미가 있는 연구가 될 것이라고 사료된다.

\section{요 약}

비예기항체(unexpected antibody)는 $\mathrm{ABO}$ 혈액형 항체와 는 달리 존재 여부를 미리 예측할 수 없는 항체로 주로 임신이나
수혈 등에 의해 다른 적혈구 항원에 노출됨으로써 발생하는 면 역항체로서, 비예기항체는 해당 항원을 가진 수혈된 적혈구를 파괴하여 급성 및 지연성 용혈성부작용이나 신생아용혈성질환 등의 수혈부작용을 유발할 수 있다. 2014년 1월부터 2016년 12 월까지 3년간 제주특별자치도 종합병원에 비예기항체 선별 검사가 의뢰된 10,360 명의 혈청 검체를 대상으로 하였으며, 의 뢰된 비예기항체 선별결과 양성 결과를 보인 87 검체를 대상으 로 조사하였다.

비예기항체가 선별되었던 87건 중 비예기항체 동정검사를 수탁검사기관으로 의뢰한 41 검체 $(0.40 \%)$ 대상으로 분석한 결 과 비특이항체가 8 건(19.51\%), 자가항체가 3건(7.32\%)이었다. 이들을 제외하고 항체가 동정된 것은 anti-E가 8건(19.51\%), anti-E, anti-c 복합항체가 6건(14.63\%), anti-Le, anti-Le ${ }^{\mathrm{b}}$ 복 합항체가 3건(7.32\%), anti-Le ${ }^{\mathrm{a}}$ 와 anti-Le 가 각각 2건(4.88\%) 으로 조사되었다. 단일항체로는 anti-D, anti- $\mathrm{ii}^{\mathrm{a}}$, anti-Fy, anti-Jk $^{\mathrm{a}}$, anti-Jk ${ }^{\mathrm{b}}$, anti-M, anti-P1이 각각 1건(2.44\%)로 나타 났으며 복합항체로는 anti-C+anti-D, anti-E+anti-C+anti-Jk ${ }^{\mathrm{b}}$ 가 각각 1 건(2.44\%)로 조사되었다. 단일항체가 동정된 검체는 19 건(46.34\%), 복합항체가 동정된 검체는 11 건(26.83\%)로 나 타났다.

제주지역의 종합병원은 제주시와 서귀포시에 위치한 종합병 원 7개 기관이 있으며, 모두 비예기항체 선별검사를 시행하고 있으며, 검사방법으로는 모든 검사실에서 Ortho BioVue system을 이용한 원주응집법으로 검사를 시행하고 있다. 하지 만 비예기항체 동정검사는 외부수탁기관에 의뢰하고 있는 실정 이다. 이번 연구는 최근 3 년간 제주도내 종합병원 1 개 기관에서 의 동정된 비예기항체 빈도와 분포를 분석하였지만, 점차적으 로 제주도내 다문화가정과 외국인 근로자가 증가 추세에 있어 향후 제주지역에 분포한 다수의 종합병원에서 동정되는 비예기 항체의 빈도와 분포를 비교 분석한다면 의미가 있는 연구가 될 것이라고 사료된다.

\section{Acknowledgements: None}

Funding: None

Conflict of interest: None

\section{REFERENCES}

1. Kim SM, Kim SH. Analysis of current status of chronic red blood cell transfusion. Korean J Blood Transfus. 2016;27(3):229-236.

2. Yoo DW, Lee HJ, Lee SM, Kim IS, Song DY, Chang CH, et al. Delayed hemolytic transfusion reaction with alloimmunization 
of Rh phenotype: A two-case study. Korean J Blood Transfus. 2017;28(2):163-169.

3. Kim MH, Suh JT, Lee WI. The frequency of unexpected antibodies in transfusion candidates in recent 6 years. Korean J Blood Transfus. 2004;15(2):162-167.

4. Cho YK, Kim DS, Lee HS, Choi SI. The frequency and distribution of unexpected antibodies in surgical patients at chonbuk national university hospital. Korean J Lab Med, 2004; 24(1):67-71.

5. Kim WD, Lee YH. A fatal case of severe hemolytic disease of newborn associated with anti-Jk(b). J Korean Med Sci. 2006;21(1):151-154.

6. Song DH, Moon IS, Hong SJ, Park JH, Kim JK, Jeon DS. Frequency and distribution of unexpected antibodies of Koreans. Korean J Blood Transfus. 1998;9(2):191-200.

7. Heddle NM, Soutar RL, O'Hoski PL, Singer J, McBride JA, Ali Ma, et al. A prospective study to determine the frequency and clinical significance of alloimmunization post transfusion. $\mathrm{Br} \mathrm{J}$ Haematol. 1995;91(4):1000-1005.

8. Kang HJ, Ihm CH, Lee MH, Hyun SH, Kim IS. The frequency and distribution of unexpected antibodies at a tertiary hospital in Daejeon. Korean J Clin Lab Sci. 2010;42(2):63-70.

9. Yang SS, Yang HJ, Park HJ, Kwon SW. The frequency and distribution of unexpected red cell antibodies and analysis of antigen exposure. Korean J Clin Lab Sci. 2013;45(4):164-169.

10. Lapierre Y, Rigal D, Adam J, Josef D, Meyer F, Greber S, et al. The gel test: a new way to detect red cell antigen-antibody reactions. Transfusion. 1990;30(2):109-113.

11. Chae SL, Bang KH, Chang EA, Cha YJ. An evaluation of gel test for irregular antibody screening. Korean J Blood Transfus. 1998;9(1):31-36.

12. Lee WH, Kim SY, Kim HO. The incidence of unexpected anti- bodies in transfusion candidates. Korean J Blood Transfus. 2000;11(2):99-103.

13. Kim DJ, Sung HH, Park CE. Investigation of red cell antibody screening tests Gyeonggi areas. Korean J Clin Lab Sci. 2016; 48(1):36-40.

14. Lee GH, Gye HI, You SY, Chung CH, Cho MJ, Kim DE. Factors influencing the sensitivity of antibody screening tests with microplate and column agglutination method. Korean J Clin Lab Sci. 1998;30(2):193-198.

15. Kretschmer V, Heuckeroth A, Schylzki T, Dietrich G. Superiority of gel centrifugation in antibody screening and identification. Transfus Med Hemother. 1992;19(5): 226-230.

16. Bromilow IM, Adams KE, Hope J, Eggington JA, Duguid KM. Evaluation of the ID-gel test for antibody screening and identification. Transfus Med. 1991;1(3):159-161.

17. Jung TK, Lee NY, Bae HG, Keon EH, Park SH, Suh JS. Unexpected antibody positivity with the use of the LISS/ Coombs gel test. Korean J Clin Pathol. 2001;21(5):422-425.

18. Park BM, Song YK, Kim TS, Lee GH, Choi JS, Seong MW, et al. The frequency and distribution of unexpected red cell antibodies at National Cancer Center. Korean J Blood Transfus. 2009;20(2):120-128.

19. Shin SA, Lee YS, Yoon KK, Kim YA. The frequency of unexpected antibodies and clinical characteristics of transfusion candidates in a general hospital during the past 12 years. J Lab Med Qual Assu. 2012;34(2):99-105.

20. Kim JE, Kim BR, Woo KS, Han JY, Kim KH. The characteristics of concurrent blood group antibodies detected by unexpected antibody screening tests. Korean J Blood Transfus. 2010;21(2): 115-121.

21. Kim JW, Kim WJ. Studies on the RBC alloimmunization after blood transfusions. J Exp Biomed Sci. 2006;12(1):35-42. 